\title{
Venomous and poisonous arthropods: identification, clinical manifestations of envenomation, and treatments used in human injuries
}

\author{
Vidal Haddad Junior ${ }^{[1]}$, Paulo Cezar Haddad de Amorim ${ }^{[2]}$, \\ William Teixeira Haddad Junior ${ }^{[3]}$ and João Luiz Costa Cardoso ${ }^{[4]}$
}

[1]. Faculdade de Medicina de Botucatu, Universidade Estadual Paulista, Botucatu, São Paulo, Brasil. [2]. Faculdade de Medicina de Catanduva, Fundação Padre Albino, Catanduva, São Paulo, Brasil. [3]. Faculdade de Medicina de Ribeirão Preto, Universidade de São Paulo, Ribeirão Preto, São Paulo, Brasil. [4]. Clínica Privada, Ubatuba, São Paulo, Brasil.

\begin{abstract}
This review presents the main species of venomous and poisonous arthropods, with commentary on the clinical manifestations provoked by the toxins and therapeutic measures used to treat human envenomations. The groups of arthopods discussed include the class Arachnida (spiders and scorpions, which are responsible for many injuries reported worldwide, including Brazil); the subphylum Myriapoda, with the classes Chilopoda and Diplopoda (centipedes and millipedes); and the subphylum Hexapoda, with the class Insecta and the orders Coleoptera (beetles), Hemiptera (stink bugs, giant water bugs, and cicadas), Hymenoptera (ants, wasps, and bees), and Lepidoptera (butterflies and moths).
\end{abstract}

Keywords: Bites and stings. Venomous animals. Venomous arthropods. Poisonous arthropods.

\section{INTRODUCTION}

Arthropods belong to the invertebrate Phylum Arthropoda. The name arthropod comes from the Greek arthron meaning joint and pod, meaning foot, which is one of their characteristic features. They also have an external skeleton, or exoskeleton, made of chitin. The Arthropoda phylum contains the most species on Earth, mainly due the number of animals in the Insecta Class ${ }^{(1)(2)(3)(4)(5)(6)}$.

Arthropod species use toxins for defense and to kill prey. Some individuals are poisonous (e.g., certain beetles release toxins when pressed or crushed), whereas others inject venom using an apparatus, which can cause systemic repercussions in the prey, as observed with the stings of certain spiders and scorpions $^{(3)(4)(5)(6)}$.

The classification of arthropods uses subphyla, classes, and orders. The subphylum Chelicerata and class Arachnida includes spiders and scorpions, which are responsible for the most human injuries worldwide. In the subphylum Myriapoda, the classes Chilopoda and Diplopoda (centipedes and millipedes) also cause human harm. The subphylum Hexapoda includes the class Insecta, with both poisonous and venomous representatives, especially in the orders Coleoptera (beetles), Hemiptera (stink

Corresponding author: Dr. Vidal Haddad Junior. Depto. de Dermatologia/FMB/ UNESP. Rubião Jr, 18618-970 Botucatu, São Paulo, Brasil.

Phone: 5514 3882-4922

e-mail: haddadjr@fmb.unesp.br

Received 15 July 2015

Accepted 24 August 2015 bugs, giant water bugs, and cicadas), Hymenoptera (ants, wasps, and bees), and Lepidoptera (butterflies and moths) ${ }^{(1)(2)}$ (Table 1).

The Health Ministry notification system focuses on human injuries caused by snakes, spiders, and scorpions because of the risk of systemic complications and death, but the most common envenomations are likely caused by caterpillars, ants, and bees ${ }^{(5)(6)}$.

\section{SUBPHYLUM CHELICERATA}

\section{Class Arachnida}

Among the venomous animals, spiders and scorpions are responsible for the most envenomations in Brazil (Figure 1).

Spiders. The main species of spiders associated with severe envenomation are: 1) Australian funnel web spiders: these large, aggressive spiders are found in Australia and belong to the genera Atrax, Hadronyche, and Illawarra. The venom is toxic to sodium channels, which results in the massive release of neurotransmitters. Envenomation can lead to arterial hypertension/hypotension, pulmonary edema, intracranial hypertension, and death. Envenomation can be treated with specific antiserum. 2) Armadeiras, banana spiders, or Brazilian wandering spiders: These large, extremely aggressive spiders sometimes attack without provocation and can leap up to $20 \mathrm{~cm}$ on the victim. These armadeiras assume an attack position before biting. The spiders are common and the most important species is Phoneutria nigriventer (Phoneutria means killer in Ancient Greek). According to Health Ministry data, banana spiders rank second among spiders causing injuries in Brazil. Manifestations of envenomation are similar to those of the funnel web spider, including alternating symptoms of neurological 
TABLE 1 - Zoological classification of the venomous and poisonous arthropods.

Poisonous and venomous arthropods

Subphylum Chelicerata

Class Arachnida: spiders and scorpions

Subphylum Myriapoda

Classes Chilopoda and Diplopoda: centipedes and millipedes

Subphylum Hexapoda

Class Insecta

origin and arterial hypertension resulting from toxic action on sodium channels and the release of neurotransmitters. Children and debilitated individuals are at higher risk of death. Bites often occur in households because of the wandering nature of the spider as it seeks prey (especially cockroaches). The pain resulting from a bite is excruciating and there is discrete inflammation at the site of envenomation. Affected individuals may present with hypertension, nausea, vomiting, priapism, cardiac arrhythmias, pulmonary edema, shock, and death ${ }^{(3)(4)(5)(6)}$. Mortality is generally low and a small proportion of cases (less than $2 \%$ ) need antivenom serum ${ }^{(3)}$. Pain can be controlled with nerve block anesthesia (consisting of a maximum of three sequential infiltrations of about $4 \mathrm{ml}$ of lydocaine without epinephrine, half in children). When antiarachnidic serum is needed, as with children and weak individuals showing systemic signs and symptoms, the number of ampoules needed is determined by the condition of the victim. A range of 2-10 ampoules may be administered intravenously, and each vial contains $5 \mathrm{ml}$ of serum ${ }^{(3)(4)(5)(6)}$. 3) Brown-spiders: Loxosceles spiders live in dark, dusty environments. They are shy and only bite when pressed or handled. The most important component of their venom is sphingomyelinase $\mathrm{D}$, an enzyme that destabilizes vessel walls and red blood cell membranes and causes extensive skin necrosis and hemolysis with the risk of acute renal failure (the latter is seen in $5 \%$ of patients) ${ }^{(5)(6)}$. Local symptoms can include a burning sensation or moderate pain. In a few hours, an extremely painful ischemic area with pallor, cyanosis, and erythema develops, creating the characteristic marble plaque. The plaque may also have hemorrhagic blisters. Full necrosis manifests in approximately seven days, resulting in a blackened and insensitive eschar adhered to the deep skin layers ${ }^{(5)}(6)$. The deployment of the eschar occurs after approximately one month, leaving an extensive and deep ulcer with a granular base and raised edges. These ulcers may resemble those caused by mucocutaneous leishmaniasis, cutaneous tuberculosis, squamous cell carcinoma, and sporotrichosis. The ulcer may take several months to heal. Treatment depends on the stage of the envenomation and there is no established timeframe

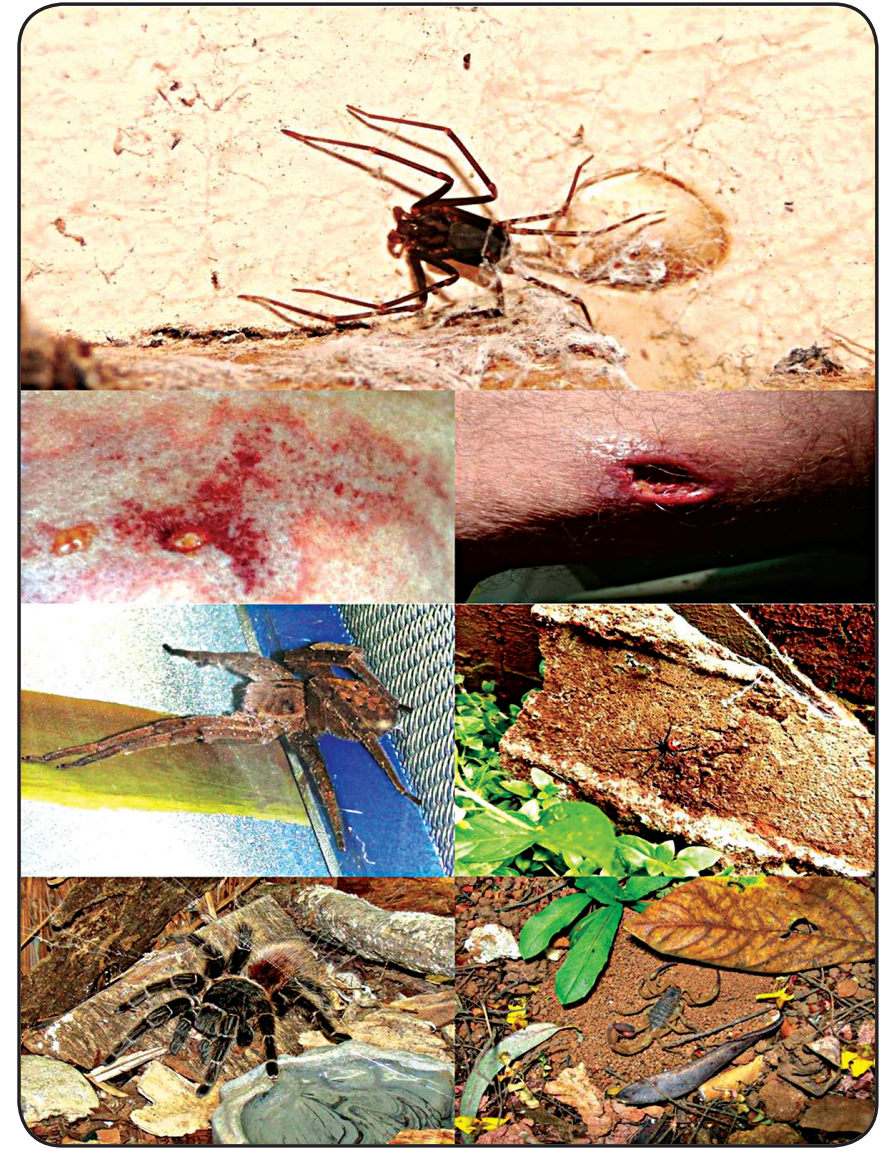

FIGURE 1 - Above, left: Loxosceles sp., the brown spider; a marble plaque; and a chronic ulcer caused by a bite from this species. Below, left: Phoneutria nigriventer, the banana spider; Latrodectus curacaviensis, the black widow; a Migalomorpha spider; and Tityus serrulatus, the yellow scorpion. Photographs: Vidal Haddad Junior and Clêndisso Rodrigues (Latrodectus).

for the use of antiaracnidic serum. Moderate cases (systemic changes without hemolysis) may need 5 ampoules and severe cases (with hemolysis) may require up to 10 ampoules. When there is necrosis without hemolysis, it is possible to use sulfone (100-300mg/day orally), which acts by blocking neutrophil diapedesis and inhibiting the extension of necrosis. The administration of oral corticosteroids is controversial, but indicated in some protocols. In later stages, extensive and slow healing ulcers can be treated with skin grafts ${ }^{(3)(4)(5)(6)}$. Cutaneous loxoscelism is not uncommon. Thousands of bites are reported annually in Curitiba, State of Paraná, Brazil. The Vital Brazil Hospital (Instituto Butantan) sees an average of 50 cases per year ${ }^{(6)}$. 4) Black widow spiders: These spiders are represented worldwide by the Latrodectus genus, with Latrodectus mactans being the most important species in the Americas, for the severity of the envenomation. The brown widow (Latrodectus geometricus) is a common spider that causes less serious injury. These spiders have a characteristic hourglass design on the ventral abdomen. The venom of the black widow causes myalgias, paresthesias, muscle contractures, drooling, 
nausea, vomiting, arterial hypotension, shock, and death in some cases. The species Latrodectus curacaviensis (flamenguinha) predominantly causes injuries in the States of Rio de Janeiro and Bahia. Treatment requires 1 or 2 antilatrodectic serum vials, depending on the severity of the symptoms. Benzodiazepines are also used to promote muscle relaxation ${ }^{(3)(4)(5)(6)}$. 5) Other spiders: Wolf spiders $(L y \cos a)$ are common in urban areas. Their bite is moderately painful but does not cause significant envenomation. Tarantulas (Mygalomorphae) are giant spiders of up to $20 \mathrm{~cm}$ in length whose venom is mildly toxic to humans. When threatened, these spiders can shoot abdominal bristles that cause an erythematous papular dermatitis in people who keep the spiders as pets or work in vivariums. Treatment of the dermatitis is symptomatic, with antihistamines and topical corticosteroids ${ }^{(5)(6)}$.

Scorpions. Scorpions live in hot climates and cause a large number of human injuries each year. Of the approximately 20,000 envenomation cases registered by the Notification System of the Health Ministry of Brazil each year, approximately 8,000 are caused by scorpions. The venom of scorpions has adapted to help the animal kill its prey by promoting the release of neurotoxins and neurological transmitters that lead to central and peripheral nervous system effects.

In Brazil, the yellow scorpion (Tityus serrulatus) is considered the most dangerous species because it is associated with the most deaths reported to the Health System of the Health Ministry of Brazil (Figure 1). Tityus obscurus of the Amazon region causes prolonged neurological manifestations with tetany and twitching.

The scorpion uses a stinger on the telson, the last segment of the tail. The venom disrupts the autonomic nervous system by dissociating the parasympathetic and sympathetic nervous systems $^{(3)(4)(5)(6)}$. The sting causes intense local pain (with minor inflammation), tachycardia/bradycardia, intense sweating, salivation, abdominal cramps, hypothermia, arterial hypo-/ hypertension, mydriasis/miosis, pulmonary congestion, cardiac arrhythmias, priapism, and acute pulmonary edema. Death can occur in children and debilitated individuals.

Treatment in mild cases (which are the absolute majority of envenomations) is nerve block anesthesia using $2 \%$ lidocaine for pain control (3-4ml in adults and $1-2 \mathrm{ml}$ in children; application can be repeated up to 3 times at 30- to 60-min intervals). The use of oral painkillers may also be useful. In moderate and severe cases, which occur mainly in children, antivenom serum is indicated. Antiscorpionic or antiaracnidic serum is used at a dose of 4 vials for mild cases (systemic manifestations are present but not intense) and 8 ampoules for severe cases (severe systemic manifestations including serial episodes of vomiting are observed). The serum should be given intravenously without dilution. The main causes of deaths are acute pulmonary edema and cardiovascular shock ${ }^{(4)(5)(6)}$.

\section{SUBPHYLUM MYRIAPODA}

\section{Class Diplopoda (piolhos-de-cobra, centopéias, gongolôs, embuás, millipede)}

Millipedes have an elongated body composed of various segments with two pairs of legs. They are poisonous animals and release toxins when pressed or crushed (Figure 2). Millipedes often enter homes and retreat to dark places, which is why many victims are bitten while putting on a shoe. Their body fluids contain toxins (cyanides and quinones) that initially cause skin and mucous membrane inflammation, and later lead to a blackish-brown hyperpigmentation at the contact location. The dermatitis does not have major clinical repercussions, but may concern the patient and a physician who is unaware of the disease. The hyperchromic lesions can persist for months $^{(6)}{ }^{(7)}(8)$, but these inflammatory and chronic injuries ultimately disappear spontaneously. Applying alcohol and ether soon after contact appears to be useful because these agents can be toxin solvents. Ocular lesions should be washed extensively because this exposure can lead to blindness ${ }^{(6)(7)(8)}$.

\section{Class Chilopoda (lacraias, centipedes)}

Centipedes are carnivorous arthropods that also have a segmented body, but have only one pair of legs on each segment. (Figure 2). The first segment has two large forcipules that originate from the first pair of legs, which can inject venom contained in glands in the trunk of the animal and can be used in defense or to catch prey. The Scolopendra genus reaches up to $25 \mathrm{~cm}$ long and causes the most serious injuries ${ }^{(6)}$.

The bite of a centipede causes intense pain, with local erythema and edema. In some cases, headache, malaise, anxiety, and dizziness are also observed. Rare reports of human deaths are quite unconvincing and secondary infection is the main complicating factor of the injury ${ }^{(6)}$.

Almost all envenomations caused by centipedes spontaneously resolve without complications. The site of the bite should be washed with soap and water and cold compresses are useful. Systemic analgesics are recommended to control the pain.

\section{SUBPHYLUM HEXAPODA}

\section{Class Insecta}

Insects are arthropods that have their name from Latin insectum, which signifies body cut in sections. They present body in three parts, an exoeskeleton composed of chitin and jointed legs. The Insecta is composed by more than one million of species (about half of the living organisms in the Earth). Some insects can cause human envenomations.

\section{Order Coleoptera}

Beetles. Envenomations caused by vesicant beetles are reported on every continent, excepting the Poles. The genera of beetles that most commonly provoke a linear or vesicular dermatitis in humans are Paederus (potós), Lytta, and Epicauta (Figure 3). The Paederus (family Staphylinidae), produces pederin and other toxins, which are powerful irritants to the skin and mucous membranes ${ }^{(1)(2)(3)(4)(5)(6)}$. While the potós were already known to the Chinese for 1,200 years, the associated dermatitis was first described in Brazil by Pirajá da Silva ${ }^{(9)}$. Lytta and Epicauta belong to the family Meloidae and feed on plants and produce cantharidin. In general, the beetles are attracted to artificial lights and enter homes or congregate in large quantities under lampposts and are also commonly found in corn and bean crops in warm, rainy months. 


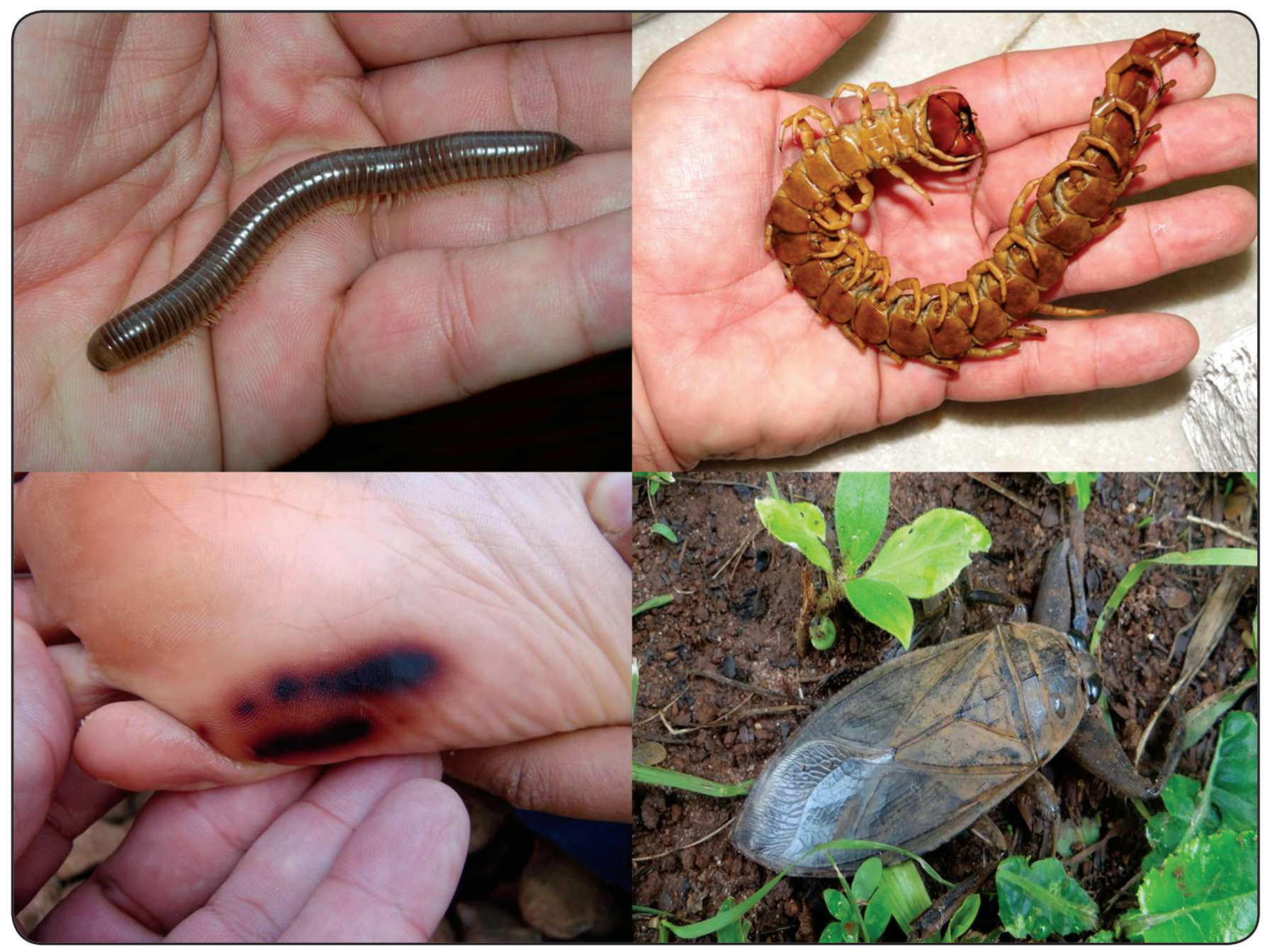

FIGURE 2 - Above: millipede and centipede myriapods. Below: hyperchromic lesions caused by a centipede and a Belostomatidae giant water bug. Photographs: Vidal Haddad Junior.

The hemolymph of the Paederus beetles contains multiple toxins, with the most important being pederin, a crystalline amide with potent vesicant and caustic actions that is soluble in water and alcohol. The toxins of the Paederus spp. cause intense erythema, edema, and vesicles, which converge to form blisters. The burning and itching symptoms of envenomation by the Paederus are more intense than those caused by Lytta and Epicauta beetles ${ }^{(10)(11)}$.

Compression of the animal liberates toxins that often affect the posterior cervical region, face, or upper limbs of the victim. The lesions are elongated or linear, resulting from skin contact with the insect ${ }^{(5)(10)(11)}$. Some cases may present with systemic symptoms such as nausea, vomiting, and fever. The skin becomes erythematous and pruritic, with a burning sensation and vesicles that evolve into sterile pustules, ulcerations, and crusts. The manifestations resolve in approximately a week, leaving residual erythematous hyperchromic macules.

Treatment should be started with intensive washing of the affected area with soap and clean water. In established lesions, the use of potassium permanganate is useful, $(1: 40,000$, or 1 tablet in $4 \mathrm{~L}$ of water) twice a day with corticosteroid creams. If there is secondary infection, the use of systemic antibiotics is necessary ${ }^{(5)}$.

\section{ORDER HEMIPTERA}

\section{Family Pentatomidae}

The insects of the family Pentatomidae (stink bugs, mariasfedidas, fedes-fedes) cause contact skin injuries that are similar to those associated with Paederus beetles ${ }^{(12)}$ (Figure 3). The crushing of these hemipterans against the skin causes vesicular and erythematous plaques on exposed areas, which are accompanied by a burning sensation and pruritus. Treatment is similar to that employed in the linear dermatitis caused by vesicant beetles ${ }^{(12)}$.

\section{Family Belastomatidae}

Insects of the family Belostomatidae cause painful stings in humans ${ }^{(13)}$. The water cockroaches, arauembóias, or giant water bugs are worlwide insects classified into two main genera (Lethocerus and Belostoma). These large insects are found in freshwater habitats and they are voracious predators, capable of hunting tadpoles and fish $^{(5)}$ (Figure 2). 


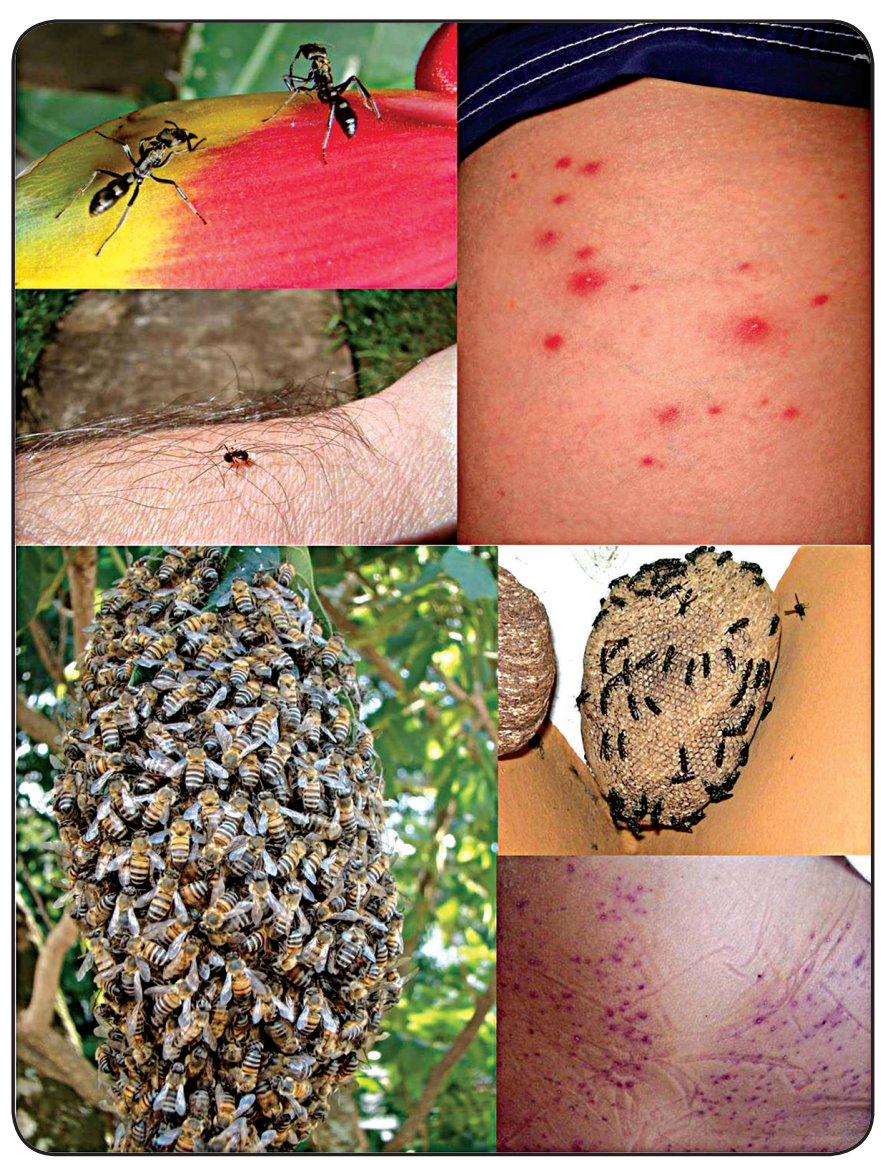

FIGURE 3 - Hymenoptera arthropods. Above, left: tocandira and fire ants. Above, right: pustules caused by stings of fire ants. Below: bees and wasps. Below, right: a massive envenomation caused by hybrid bees. Photographs: Vidal Haddad Junior.

Giant water bugs can reach $10 \mathrm{~cm}$ in size. They have a short stout beak that is used to pierce their prey and inject toxic saliva composed of enzymes that can liquefy the tissues of the prey ${ }^{(14)(15)}$. There are reports of lysophospholipids in the saliva of the species Belostoma anurum that can cause paralysis in the neuromuscular junctions of the prey ${ }^{(16)}$. These insects can produce very painful lesions in humans and may also carry infections. The treatment for the sting is symptomatic.

\section{ORDER HOMOPTERA (CICADAS)}

\section{Family Fulgoridae (Jequitiranabóias)}

Many superstitions surround the jequitiranabóias, or cicadas of the Fulgora genus. Called flying snakes, jitiranas, or snakes-of-wings by the rural population of South America, they are believed to be highly venomous to humans (Figure 3). Another unsubstantiated belief is that the insect kill the trees that it lands. In truth, these insects are completely harmless to humans ${ }^{(3)}$.

\section{Order Hymenoptera (ants, bees and wasps)}

Ants. Ants belong to the family Formicidea and their stings are common in humans, particularly in rural areas. Select species cause serious complications owing to the toxicity of their venom or provocation of allergic reactions ${ }^{(17)(18)}$ (Figure 4).
The most venomous ants are the bullet ants (tocandira, tocandeira, or twenty-four hour ant). Belonging to the genera Paraponera and Dinoponera, they can measure several centimeters long and have dark coloring. These ants are either solitary or live in small groups on fallen logs and rotting wood, and are found in South and Central America. The tocandira injects its venom from an abdominal stinger connected to a venom gland. The venom is a little studied protein mixture that is used by Brazilian Indians for the control of rheumatic pains. In addition, the ants are used as main part of a coming-of-age ritual of the Amazonian tribe Sateré-Maué in which youngsters introduce their hands into gloves filled with ants to test their self-control in the presence of intense pain ${ }^{(19)}$.

The red lava-pés ants or fire ants (Solenopsis invicta) originated in Brazil, but they were introduced to Louisiana and have since spread throughout the United States. These carnivorous ants eat a variety of prey, from insects to small mammals. The venom of this species is composed of alkaloids (originated from plant extracts), which is different than most other animal venoms, which are formed of proteinaceous material. Solenopsin A is the component of the venom that has a cytotoxic effect and causes degranulation of mast cells. There are also non-toxic proteins that can trigger allergic reactions.

Fire ants use their jaws to attach to the skin of their prey and they can sting up to 10 times with their abdominal stinger. Initial manifestations include pain, an itchy, burning sensation, and an urticated papule. Within 24 hours, the papule evolves to a sterile pustule. Multiple stings are common and cause pustulosis in children or alcoholized individuals and secondary infections can occur ${ }^{(17)(18)}$. Allergic reactions are common and can progress to anaphylactic shock. Vaccines protecting against allergic reactions to fire ants (Solenopsis invicta) are available in the United States, but have controversial results ${ }^{(17)(18)}$. Once Pseudomyrmex ants have established themselves in a Triplaris sp. tree, they will attack humans that come into contact with the tree. Their stings cause intense pain and discrete to moderate inflammation at the site of the sting ${ }^{(20)}$. The problem is common in some Brazilian regions and can be prevented by proper identification and avoidance of Triplaris sp. trees.

Ant stings are treated symptomatically with antihistamines, cold compresses to control pain, and topical corticosteroids. Massive stings should be treated with oral corticosteroids (prednisone, $30 \mathrm{mg} /$ day). An allergic reaction to ant stings should receive the same care as an allergy to bee stings ${ }^{(5)(18)}$.

Bees and wasps. Bees and wasps are venomous social insects that inject venom using a stinger in the abdomen (Figure 4). The venom provokes local reactions (papules with moderate pain and inflammation) and systemic phenomena (with multiple stings, causing myoglobinuria, renal failure, heart failure, and death). The allergic manifestations can progress to anaphylactic shock. The aggressive hybrids of African and European bees originated in Brazil and have caused various envenomations and deaths across the Americas. More than 100 stings increases the risk of death. The venom is rich in phospholipases and can cause multiple organ failure ${ }^{(3)(5)(21)}$.

The stingers remain adhered to the skin and if the venom gland is pressed, more content is inoculated. Careful removal 


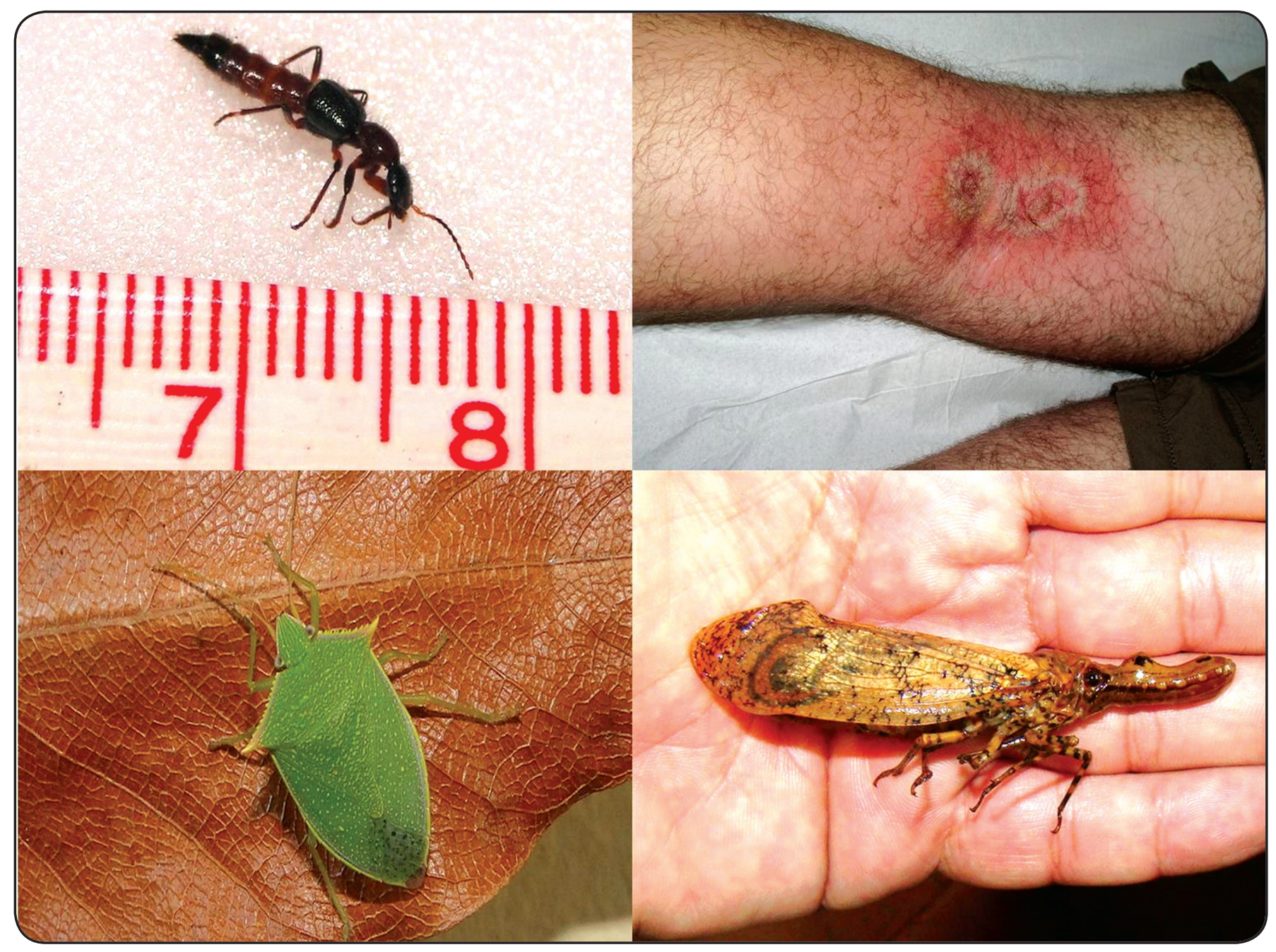

FIGURE 4 - Above: vesicant beetle (Paederus sp.) and lesions caused by the beetle. Below: stink bug (Pentatomidae) and Fulgora cicada (jequitiranabóia). Photographs: Vidal Haddad Junior.

of the remaining stingers modifies the prognosis of the victim of envenomation. The treatment of one to a few bee or wasp stings can consist of antihistamines and topical corticosteroids, but severe toxicity will require symptomatic treatment because there is no antivenom for bee stings. Appropriate emergency room treatment includes systemic corticosteroids, antihistamines, and millesimal adrenaline owing to the high risk of death ${ }^{(3)(5)(21)}$.

\section{ORDER LEPIDOPTERA (MOTHS AND CATERPILLARS)}

In hot and rainy months, moths of the genus Hylesia (family Saturniidae) mate and the females release clouds of the abdominal bristles. The bristles cause an intense dermatitis, or lepidopterism, manifested by erythematous and edematous papules and pruritus $^{(3)(5)(22)(23)(24)(25)}$. Some authors believe that there are toxins in the bristles ${ }^{(5)}$. There is also the risk of severe ophthalmic involvement. Treatment recommendations include oral antihistamines for the itch, cold compresses, and topical corticosteroids.

Erucism (erucae $=$ larvae) is caused by the larvae of moths or caterpillars (Figure 5). The condition is characterized by intense pain associated with mild local inflammation and in some cases, a painful regional lymphadenopathy. Some cases present with severe local inflammation, which can provoke vesicles, blisters, and superficial necrosis ${ }^{(3)(5)(22)(23)}$. The manifestations persist for 24-48 hours. Erucism may be the most common envenomation around the world because of the proximity of these larvae to human beings, especially children. The venom contains histamine and similar substances ${ }^{(3)(5)(22)(23)}$.

The main families of Lepidoptera that causes erucism are Megalopygidae and Saturniidae. The family Megalopygidae comprises two important genera: Podalia and Megalopyge. Megalopigidae caterpillars are completely covered with bristles, while the family Saturniidae has bristles that resemble small pine trees. The most important genera associated with human injuries are of the family Saturniidae are Automeris, Dirphia, and Lonomia. The genera Lonomia and Periga, which are common in Central and South America, cause painful stings that lead to a hemorrhagic syndrome characterized by a decrease in fibrinogen and/or platelet aggregation inhibition. The presence 


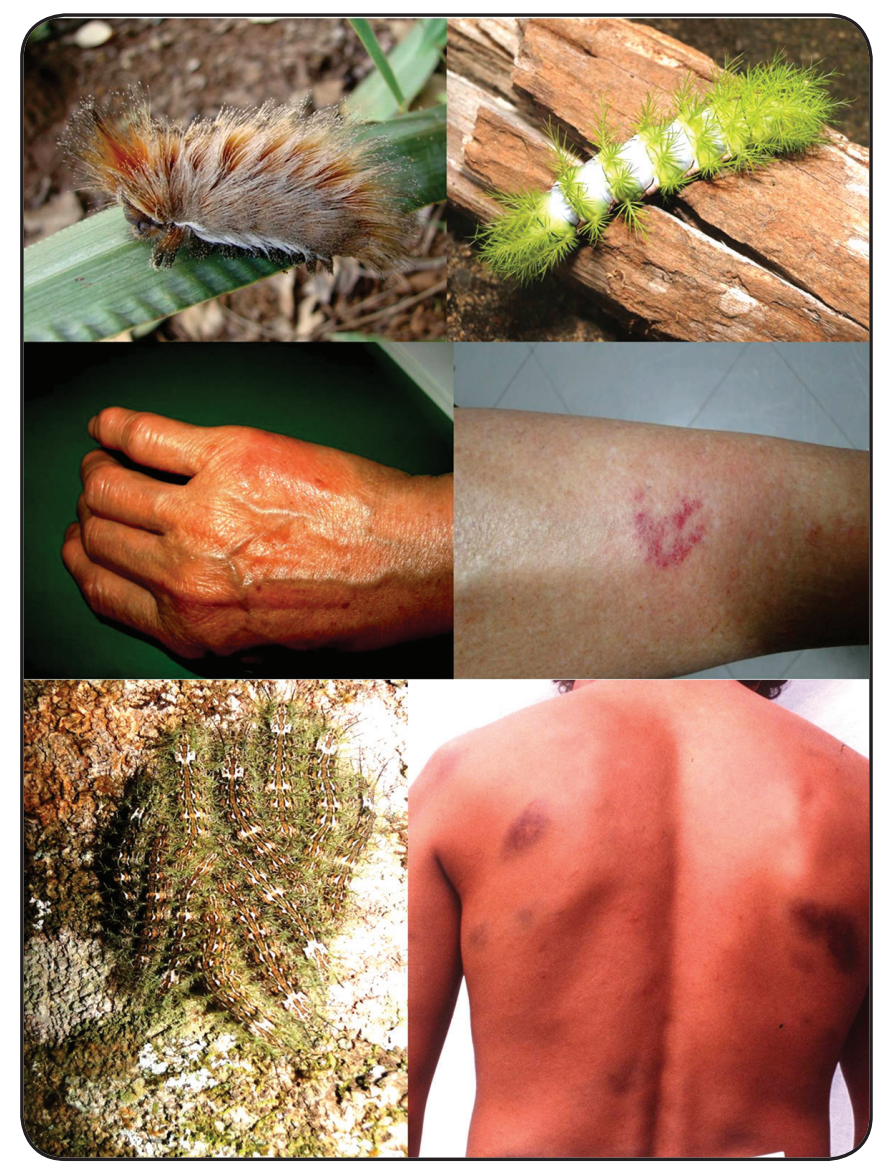

FIGURE 5 - Above: Megalopygidae and Saturniidae caterpillars with respective lesions caused in humans. Below: Lonomia sp. and coagulation alterations in a patient who came into contact with a colony. Photographs: Vidal Haddad Junior.

of ecchymosis and hemorrhagic suffusions in a victim after contact with a caterpillar indicates the possibility of contact with these specific species ${ }^{(3)(5)(22)(23)(26)}$. Victims of envenomation caused by Lonomia and Periga caterpillars that present with bleeding need hospitalization and treatment with the antivenom serum produced at the Butantan Institute, São Paulo, Brazil.

Pararamose is caused by caterpillars of the species Premolis semirufa in rubber tree workers of the Amazon region. Victims may be exposed as they collect sap from the rubber trees and come into contact with the potentially venomous bristles of the caterpillars, thereby setting up an initial inflammatory reaction. The edema persists for two to three days and a progressive fibrosis occurs that leads to ankylosis and loss of function in the joints of the hands ${ }^{(3)(5)(27)}$. The arthritis caused by the pararama provokes serious sequelae, once the arthritis progresses to full incapacitation of the hand joints.

The diagnosis of erucism is straightforward because the victim usually brings the caterpillar. The best method to control the pain is nerve block anesthesia with $2 \%$ lidocaine, but in children (the majority of victims), the recommendation is to apply topical commercial anesthetic creams with $0.25 \%$ lidocaine and $0.25 \%$ prilocaine ${ }^{(28)}$. Additional treatments include the application of cold compresses, oral antihistamines, and topical corticosteroids, which reduce local inflammation, but not the pain.

\section{CONCLUSIONS}

A great number of arthropods are venomous and their toxins provoke complex and sometimes fatal manifestations in humans. Knowledge of these envenomations and how to treat human victims appropriately is very important to professionals working in tropical medicine and emergency centers.

\section{CONFLICT OF INTEREST}

The authors declare that there is no conflict of interest.

\section{REFERENCES}

1. Alexander JD. Arthropods and human skin. London: Springer Verlag; 1984.

2. Goddard J. Arthopods of medical importance. Florida: CRC Press; 1993.

3. Cardoso JLC, França FOS, Wen FH, Malaque CMS, Haddad Jr V. Animais peçonhentos no Brasil: biologia, clínica e terapêutica. São Paulo: Editora Sarvier; 2009.

4. Ministério da Saúde. Manual de diagnóstico e tratamento de acidentes por animais peçonhentos. $2^{\text {nd }}$ ed. Brasília: Fundação Nacional de Saúde; 2001.

5. Haddad Jr V, Cardoso JL, Lupi O, Tyring SK. Tropical dermatology: venomous arthropods and human skin: part I: Insecta. J Am Acad Dermatol 2012; 67:331.e1-331.e14.

6. Haddad Jr V, Cardoso JL, Lupi O, Tyring SK. Tropical dermatology: venomous arthropods and human skin: part II: Diplopoda, Chilopoda and Arachnida. J Am Acad Dermatol 2012; 67:347.e1-347.e9.

7. Haddad Jr V, Cardoso JLC. Acidentes provocados por Millepede com manifestações dermatológicas: relatos de dois casos. An Bras Dermatol 2000; 75:471-474.

8. Lima CAJ, Cardoso JLC, Magela A, Oliveira FGM, Talhari S, Haddad Jr V. Exogenous pigmentation in toes feigning ischemia of the extremities: a diagnostic challenge brought by arthropods of the Diplopoda Class (“millipedes"). An Bras Dermatol 2010; 85:391-392.

9. Pirajá da Silva M. Le Paederus columbinus est vésicant. Arch Parasitol 1912; 15:431-432.

10. Diógenes MJN. Dermatite de contato pela pederina: estudo clínico e epidemiológico no Estado do Ceará, Brazil. Rev Inst Med Trop São Paulo 1994; 36:59-65.

11. Haddad Jr V. "Sign of the kiss" in dermatitis caused by vesicant beetles (Paederus sp. or "potós"). An Bras Dermatol 2014; 89:996-997.

12. Haddad Jr V, Cardoso JLC, Moraes RC. Skin lesions caused by stink bugs (Insecta: Hemiptera: Pentatomidae): first report of dermatological injuries in humans. Wild Environ Med 2002; 13:48-50.

13. Picado C. Estudo experimental sobre o veneno de Lethocerus depontei (De Carlo) (Hemiptera, Belostomatidae). Mem Inst Butantan 1936; 10:303-310.

14. Cardoso LS, Caccin P, Fuly AL. Lysophoslipids from the saliva of the aquatic hemipteran predator Belostoma anurum cause prey paralisia. Abstract 427-1. Annals of the XVI World Congress of the IST and X Congresso da SBTx, Recife, Brazil; 2009. 
15. Haddad Jr V. Animais aquáticos potencialmente perigosos do Brasil: guia médico e biológico. São Paulo: Editora Roca; 2008.

16. Haddad Jr V, Schwartz EM, Schwartz CA, Carvalho LN. Report of seven human envenomations caused by giant water bugs of Belostomatidae family (Hemiptera, Heteroptera). Wild Environ Med 2010; 21:130-133.

17. Haddad Jr V, Cardoso JLC, França FOS, Wen FH. Acidentes provocados por formigas: um problema dermatológico. An Bras Dermatol 1996; 71:527-530.

18. Haddad Jr V, Medeiros CR. Acidentes por formigas. In: Cardoso JLC, França FOS, Wen FH, Malaque CMS, Haddad Jr V, editors. Animais peçonhentos no Brasil: biologia, clínica e terapêutica dos acidentes. $2^{\text {nd }}$ ed. São Paulo: Editora Sarvier; 2009. p. 268-273.

19. Haddad Jr V, Cardoso JLC, Morais RHP. Description of an injury in a human caused by a false tocandira (Dinoponera gigantea, PERTY, 1883) with a revision on folkloric, pharmacological and clinical aspects of the giant ants of the genera Paraponera e Dinoponera (sub-family Ponerinae). Rev Inst Med Trop São Paulo 2005: 47:235-238.

20. Haddad Jr V, Bicudo LRH, Fransozo A. The Triplaria tree (Triplaris spp) and Pseudomyrmex ants: a symbiotic relationship with risks of attacks for humans. Rev Soc Bras Med Trop 2009; 42: 727-729.

21. França FOS, Benvenuti LA, Wen FH, Dos Santos DR, Hain SH, Picchi-Martins FR, et al. Severe and fatal mass attacks by "Killer" bees (Africanized honey bees - Apis mellifera scutellata) in Brazil: clinicopathological studies with measurement of serum venom concentrations. Q J Med 1994; 87:169-182.
22. Cardoso AEC, Haddad Jr V. Acidentes por Lepidópteros (larvas e adultos de mariposas): estudo dos aspectos epidemiológicos, clínicos e terapêuticos. An Bras Dermatol 2005; 80:571-575.

23. Haddad Jr V, Cardoso JLC. Erucismo e lepidopterismo. In: Cardoso JLC, França FOS, Wen FH, Malaque CMS, Haddad Jr V, editors. Animais peçonhentos no Brasil: biologia, clínica e terapêutica dos acidentes. $2^{\text {nd }}$ ed. São Paulo: Editora Sarvier; 2009. p. 236-239.

24. Cardoso JLC, Borges Filho TS, Carneiro ECG, Moraes HP. Surto de dermatite por Hylesia paulex no litoral do Estado de São Paulo, Bertioga, verão 1990. Mem Inst Butantan 1990; 52:82.

25. Moreira SC, Lima JC, Silva L, Haddad Jr V. Relato de um surto de lepidopterismo (dermatite associada ao contato com mariposas) entre marinheiros, ocorrido em Salvador, Estado da Bahia. Rev Soc Bras Med Trop 2007; 40:591-593.

26. Da Silva WD, Campos CM, Gonçalves LR, Souza-e-Silva MC, Higashi HG, Yamaguchi IK, et al. Development of an antivenom against toxins of Lonomia obliqua caterpillars. Toxicon 1996: 34:1045-1049.

27. Costa RM. Artropatia da pararamose: epidemiologia, clínica e modelos experimentais. 1991. 92 p. (Doctor's Thesis). Escola Paulista de Medicina; 1991 São Paulo.

28. Haddad Jr V, Lastória JC. Envenomation by caterpillars (erucism): proposal for simple pain relief treatment. J Venom Anim Toxins Incl Trop Dis 2014; 20:21. 